\title{
Minimum number of common bean plants per plot to assess field resistance to white mold
}

Flávia Fernandes Carneiro $^{1 *}$, Walmes Marques Zeviani ${ }^{2}$, João Bosco dos Santos $^{3}$, Renato Sérgio Batista Carvalho ${ }^{4}$, Felipe Couto Alves $^{5}$ and Juliana Andrade Dias ${ }^{6}$

Received 13 September 2010

Accepted 9 January 2011

\begin{abstract}
This study aimed to determine the minimum number of plants per plot to assess the field resistance in common bean to white mold. Thirteen cultivars were inoculated with six isolates of Sclerotinia sclerotiorum and evaluated in a randomized block design with three replications and plots consisting of 1-m rows with 15 plants. Plants were inoculated by the straw test as proposed by Petzoldt and Dickson (1996), to evaluate partial resistance in a greenhouse. Eight days after inoculation the disease severity was evaluated on a 1-9 diagrammatic scale, where $1=$ asymptomatic plants to $9=$ plant death. To determine the minimum number of plants per plot, the following methods were used: maximum curvature, segmented linear model, quadratic segmented model and the relative CV model. There were significant differences among cultivars and isolates and no significant cultivar - isolate interaction. It was observed that eight plants per plot is an adequate number to assess the reaction of common bean to white mold.
\end{abstract}

Key words: breeding, Sclerotinia sclerotiorum, experimental design, resistance to the pathogen.

\section{INTRODUCTION}

The occurrence of diseases generally reduces productivity, causes yield instability and increases the crop risk. White mold (Sclerotinia sclerotiorum) is a particularly threatening bean disease, mainly in cultivation under center pivot irrigation, where common bean is usually planted successively in the same area and temperature and humidity conditions are ideal for the pathogen development. This fungus can cause yield reductions of up to $80 \%$ and can remain viable in the soil for up to 15 years, through resistance structures called sclerotia (Lobo Jr. and Nasser 2007).

The most effective control measure is the use of lines with pathogen resistance, which is restricted to certain genotypes that could be used in breeding programs, but not directly for production (Kolkman and Kelly 2002). Raising the resistance level in breeding programs will certainly have a significant impact on the bean production chain as areas currently unfit for cultivation, due to the high disease incidence, will be re-included in the production system and expenses with pesticides, which are not always efficient, will be reduced.

There are various evaluation procedures for white mold resistance, of which the straw test is considered the most efficient to assess physiological resistance (Téran and Singh 2009). A major problem of assessing pathogen resistance is the number of lines, usually rather large, making evaluations very labor-intensive. Evidently, the higher the number of plants per plot, the greater the effort

\footnotetext{
1,3,5,6 Universidade Federal de Lavras (UFLA), Departamento de Biologia, 3037, 37.200-000, Lavras, MG, Brazil. *E-mail: bioffc@yahoo.com.br

${ }^{2}$ Universidade Federal do Paraná (UFRP), Departamento de Estatística, 81.531-990, Curitiba, PR, Brazil

${ }^{3}$ Universidade de São Paulo, Escola Superior de Agricultura Luiz de Queiroz (ESALQ), Departamento de Genética, 13.400-970, Piracicaba, SP, Brazil
} 
expended in the ratings. However, if the number is too small, the accuracy can be reduced, decreasing the efficiency of selection (Barbosa et al. 2001, Ramalho et al. 2005). It is therefore desirable to identify the minimum number of plants per plot without affecting the efficiency of the process.

In breeding programs, the experimental error can be reduced by optimizing the number of plants per plot and number of replications, resulting in a reduction of the phenotypic variance, an increased heritability coefficient, and consequently, higher genetic gains with selection (Eberhart 1970, Leite et al. 2006). Additionally, the plot size is directly related to the cost of conducting experiments and evaluations; the optimal plot size is determined by the balance between cost and accuracy (Zhang et al. 1994, Storck et al. 2006).

Among the various methodologies for determining plot size and shape are: methods based on stabilizing the genetic and mean variance, Maximum Curvature Method, Method of Fairfield Smith, Modified Maximum Curvature Method, Method of Relative Information, Multiple Regression Method, Method of W. H. Hatheway, Method of Pimentel Gomes, Linear segmented model, Quadratic segmented model (Zanon and Storck 2000). The different methods are based on the observed relationship between plot size and residual variation, and differ in many aspects; an increase in plot size reduces plot variation, however, this decrease is finite.

Research regarding the most appropriate experimental plan to evaluate the field resistance in common bean to Sclerotinia sclerotiorum is scarce. In view of the importance of this pathogen in reducing the Brazilian grain production, studies of methods to enhance the experimental accuracy are essential. Such studies are closely related to the use of methods to determine optimum plot size. Given the above, the purpose of this study was to determine the minimum number of plants per plot in field evaluations of white mold resistance in common bean.

\section{MATERIAL AND METHODS}

The experiment was conducted at the Federal University of Lavras, Minas Gerais, Brazil, in March 2010 (minimum temperature $17^{\circ} \mathrm{C}$, maximum $27^{\circ} \mathrm{C}$, average rainfall around $180 \mathrm{~mm}$ in the evaluation period). Thirteen cultivars/lines (Table 1), with different resistance levels to white mold were inoculated with six Sclerotinia sclerotiorum isolates from different regions, three from the state of Minas Gerais and three from Goias (Table 1). The cultivars/lines with numbers 5 through 13 are adapted to southern Minas Gerais. The numbers 1 through 4 are progenies derived from backcrosses in which the donor of white mold resistance was the source G122 and the recurrent parent was line M20. G122 has large freckled grain, growth habit type II and partial physiological resistance to white mold. M20 is a carrier of resistance alleles to anthracnose $\mathrm{Co}-5$ and $\mathrm{Co}-42$, with partial resistance to bacterial blight, growth habit type II and carioca grain (Silva et al. 2006).

The experiments were conducted under field conditions. The 13 cultivars were evaluated in a randomized block design with three replications in six experiments. Each isolate represented an experiment. Plots consisted of 1-m rows with 15 plants and the 10 strongest plants per plot were inoculated. The normal cultural treatments and fertilization of common bean were applied and the crop irrigated twice a week for tw o hours.

The isolates were grown in Petri dishes containing medium potato dextrose agar (PDA) amended with chloramphenicol, at a rate of one drop of antibiotic/100mL of PDA and maintained in BOD at $20 \pm 3{ }^{\circ} \mathrm{C}$ for three days. The inoculum was multiplied and grown again under the same conditions, to increase uniformity. Three days after the second multiplication, eppendorf tubes were used with $200 \mu \mathrm{l}$ mycelium-containing agar to inoculate the plants 28 days after planting.

For inoculation, the main plant stem was cut, into which a plastic micropipette was inserted containing agar on which the mycelium was grown. Eight days after inoculation reaction of bean to white mold was evaluated on a diagrammatic 1-9 scale (Terán and Singh 2009), where: 1. plants without symptoms; 2 . invasion of the fungus beyond inoculation site; 3 . invasion of the fungus near the first node; 4 . fungus expanded to the first node; 5 . invasion of the fungus beyond the first node; 6 . invasion of the fungus near the second node; 7 . fungus expanded to the second node; 8.invasion of the fungus beyond the second node; and 9. plant death.

Variance analyses were performed for each isolate and combined. Only the isolates effective in discriminating the genotypes were included to study the effects of cultivars, isolates and cultivar - isolate interaction. Analyses were performed using SAS software (SAS Institute 2005), proc GLM.

For an increased result reliability, three well-known methods were used to determine the minimum number of plants per plot to assess white mold resistance in bean by means of the straw test: maximum curvature method, 
FF Carneiro et al.

Table 1. Common bean lines/cultivars used and their characteristics of type, 100-grain weight (g), growth habit, resistance allele to anthracnose and reaction to angular leaf spot. Isolates from different regions of the state of Minas Gerais and Goiás, used in the diallel design, with their respective names and origins

\begin{tabular}{|c|c|c|c|c|}
\hline Cultivar/line & $\begin{array}{c}\text { Grain type/ } 100 \text {-grain } \\
\text { weight }(\mathrm{g})\end{array}$ & Growth habit & $\begin{array}{l}\text { Resistance allelel to } \\
\text { anthracnose }\end{array}$ & $\begin{array}{c}\text { Reaction to angular leaf } \\
\text { spot }\end{array}$ \\
\hline 1 - RC2-G122-72 & Carioca/25 & II & $\mathrm{Co}-4^{2}$ & Resistant \\
\hline 2 - RC2-G122-67 & Carioca/22 & II & $\mathrm{Co}-4^{2}$ & Resistant \\
\hline 3 - RC2-G122-89 & Carioca/23 & II & $\mathrm{CO}-4^{2}$ & Resistant \\
\hline 4 - RC2-G122-92 & Carioca/20 & II & - & \\
\hline 5 - BRS - Cometa & Carioca/23 & II & - & \\
\hline $6-\mathrm{VC}-16$ & Carioca/25 & III & - & \\
\hline 7 - Majestoso & Carioca/25 & III & - & \\
\hline 8 - CNFRJ10564 & Pintado/42 & I & - & \\
\hline 9 - Talismã & Carioca & & & \\
\hline 10 - RP-2 & Carioca/25 & II & - & \\
\hline 11-MA-IV-18-266 & Carioca/23 & II & - & Resistant \\
\hline 12 - ESAL 550 & $\mathrm{Jalo} / 45$ & III & - & \\
\hline \multicolumn{5}{|l|}{13 - CNFC 9506} \\
\hline Isolate & Name & Origin & & \\
\hline Isolate 1 & $55-26$ & Goiânia, GO & & \\
\hline Isolate 2 & Oratórios 2002 & Viçosa, MG & & \\
\hline Isolate 3 & $55-05$ & Goiânia, GO & & \\
\hline Isolate 4 & $55-31$ & Goiânia, GO & & \\
\hline Isolate 5 & UFLA-1 & Ijaci, MG & & \\
\hline
\end{tabular}

segmented linear model, quadratic segmented model, plus a fourth methodology developed for this study. This methodology considers the amplitude between the asymptotic coefficient of variation, obtained when the number of plants per plot tends to infinity, and the maximum coefficient of variation is obtained when only one plant per plot is used. The nonlinear model used to estimate the optimal number of plants per plot is: $C V_{i}=b_{0}+\left(b_{1}-b_{0}\right) /$ $\left(1+Q^{*}\left(n_{1}-1\right) / b_{2}\right)$, where $Q=(1-q) / q . C V_{i}$ are the values of coefficient of variation $(\mathrm{CV})$ corresponding to the number of plants $n_{i}$. The parameters $b_{0}, b_{1}$ and $b_{2}$ represent $\mathrm{CV}$ with infinite plants per plot, one plant per plot and the optimal number of plants per plot, respectively, in the ideal plot, given the value $q$. The value of $\mathrm{q}$ is between 0 and 1 and corresponds to the minimum and maximum possible CV values. The difference of this methodology from the others is that the maximum and minimum CVs are considered. In other words, a value of $q$ $=0.10$ means that an ideal number of plants with a $10 \%$ higher $\mathrm{CV}$ than the minimum is desired, considering the amplitude of the CVs. If $\mathrm{q}=0$, the plot size is infinite, making the $\mathrm{CV}$ is minimal, and if $q=1$ the plot should have one plant, making the CV maximal. This model is named "relative CV model". Sampling was random, with replacement of the observation vector. 1000 resamplings were made for each number of plants per plot. The number of plants was from 1 to 20. Analysis of variance was performed, the $\mathrm{CV}$ calculated and the normality of residuals tested for each resampling. Therefore, for each number of plants per plot, a set of $1000 \mathrm{CVs}$ was obtained at the end.

The CVs estimated in the analysis of variance of the sub-samples in relation to the size of the respective subsamples were represented graphically (CV on the ordinate and number of plants per plot on the abscissa axis). It was found that from a certain number of plants per plot the $\mathrm{CV}$ values stabilized; from this point on, an increase in the number of plants per plot in the sub-samples would not cause major changes in experimental accuracy. The minimum number of plants per plot was determined visually as the point at which the $\mathrm{CV}$ estimate became stable. The resampling procedures, calculations and individual and combined analyses of variance were performed using the statistical software R, version 2.10.1 (www.rproject.org). 


\section{RESULTS AND DISCUSSION}

In the analysis of individual variance, a significant difference between the lines/cultivars can only be observed when inoculated with isolates 2,3 and 4, so these strains are more efficient in evaluating resistance to the pathogen by a better discrimination of the genotypes, making an identification of those with higher levels of physiological resistance to white mold possible.

Analysis of variance (Table 2) showed a significant difference between the lines/cultivars, indicating that they have different resistance alleles as well as a difference between strains, proving the existence of genetic differences or different allele aggressiveness. The identification of the most aggressive isolate is important for studies to evaluate resistance sources to this pathogen and may discriminate treatments more clearly and select the most resistant. Sources of resistance to the different alleles of isolates with different aggressiveness can also be identified. on the ratio between the genetic and residual variations of the character under study. It refers to the correlation between the true genotypic value of the genetic treatment and the estimated or predicted value, based on experimental data. As a correlation, it ranges from 0 to 1 , and appropriate values of accuracy are those close to unity or $100 \%$ (Resende and Duarte 2007).

When estimating the minimum number of plants per plot to assess white mold resistance in common bean, the coefficient of variation (CV) ranges from 34 to $44 \%$ in $\mathrm{CV}_{1}$ and 15 to $34 \%$ in $\mathrm{CV}_{2}$, by all four methods (Figure 1); $\mathrm{CV}_{1}$ is the plot error and $\mathrm{CV}_{2}$ the subplot error. The data set used was suitable for the proposed study, since the behavior of $\mathrm{CV}$ in relation to the plot sizes is consistent with other studies of this nature (Viana et al. 2002, Storck et al. 2005). The use of small-sized plots resulted in an increase in $\mathrm{CV}$, i.e., a higher experimental error, which directly affected the subsequent statistical analysis.

Table 2. Summary of the combined analysis of variance of the response of inoculated cultivars with isolates of Sclerotinia sclerotiorum (isolates 2, 3 and 4) that were efficient in the discrimination of the genotypes. Number of plants per plot in relation to the q value for estimation by the relative $\mathrm{CV}$ model, considering the $\mathrm{CV}$ of plots $\left(\mathrm{CV}_{1}\right)$ and of subplots $\left(\mathrm{CV}_{2}\right)$

\begin{tabular}{|c|c|c|c|c|c|}
\hline Sources of variation & df & MS & $\mathbf{F}$ & $r \hat{g} g \%$ & \\
\hline Cultivar (Cult) & 12 & 5.0033 & $8.02^{* * *}$ & 93.5 & \\
\hline Isolate (Iso) & 2 & 6.2901 & $10.08 * * *$ & 94.9 & \\
\hline Replicate/Isolate & 6 & 1.5993 & 2.56 & 78.1 & \\
\hline Cult $\mathrm{x}$ Iso & 24 & 0.5651 & 0.91 & & \\
\hline Error & 72 & 0.6241 & & & \\
\hline \multicolumn{6}{|l|}{$\mathrm{CV}(\%)=15.98$} \\
\hline$q$ & 0.05 & 0.1 & 0.15 & 0.2 & 0.25 \\
\hline $\mathrm{CV}_{1}$ & 19.6730 & 9.3188 & 5.8674 & 4.1416 & 3.1062 \\
\hline $\mathrm{CV}_{2}$ & 27.5121 & 13.0320 & 8.2053 & 5.7920 & 4.3440 \\
\hline
\end{tabular}

**** significant at $\mathrm{p}=0.005$.

It follows from the non-significant cultivar-isolate interaction (Table 2) that the reaction of cultivars was similar when inoculated with the different isolates. This indicates that the cultivars respond similarly to all isolates; it was therefore concluded that the resistance is horizontal while the strains differ in aggressiveness. Additionally, the fact that $S$. sclerotiorum infects over 400 plant species (Boland and Hall, 1994) also indicates that resistance must be horizontal. In other words, this pathogen is less developed than others who have already established a more specific host-pathogen interaction, such as a genegene interaction (Robison 1996). It is worth mentioning that horizontal resistance can occur with some genes of major effect and modifying genes (Parlevliet 1981). Along with the fact that several QTL regions have already been identified as genomic regions of white mold resistance (Miklas et al. 2001, Kolkman and Kelly 2003, Ender and Kelly 2005, Miklas 2007), these factors together indicate that the resistance to white mold must be horizontal.

The high value of selective accuracy $[\mathrm{rgg}(\%)]$, which was $93.5 \%$ for the cultivar effect and $94.9 \%$ for the isolate effect (Table 2) indicated that the experiment was conducted with a high degree of experimental precision. The selective accuracy can inform about the correct ranking of cultivars for selection purposes and also on the reliability of the genotypic value of a cultivar, ie, the VCU (Resende 2002). This parameter depends not only on the magnitude of the residual variation and the number of replications, but also 
Maximum curvature

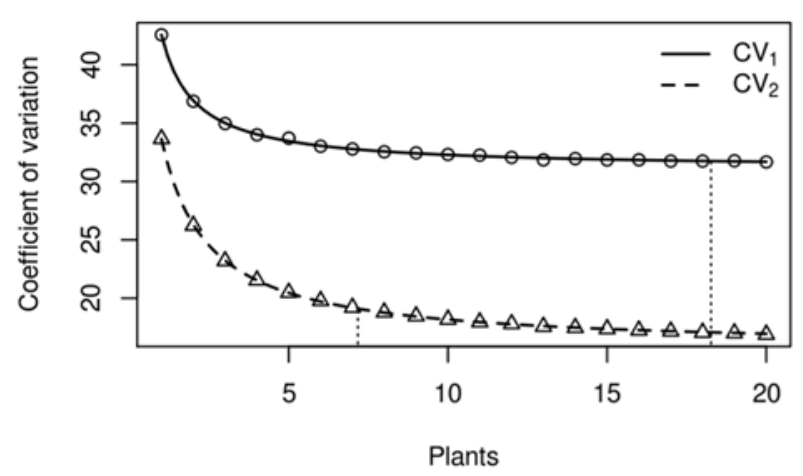

Segmented quadratic model

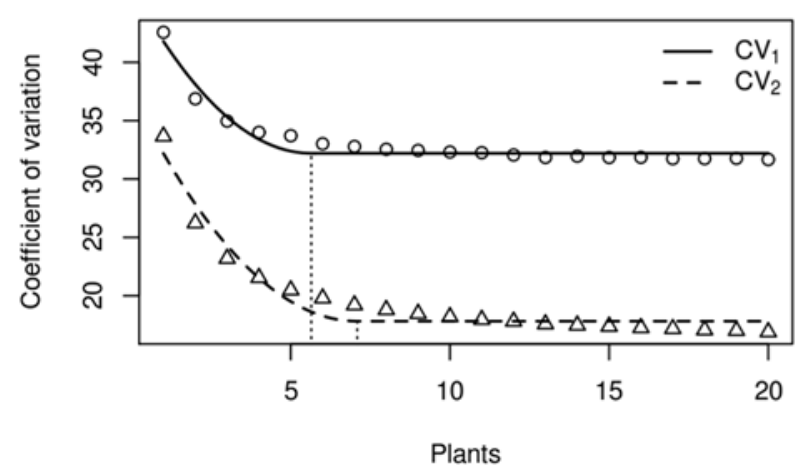

Segmented linear model

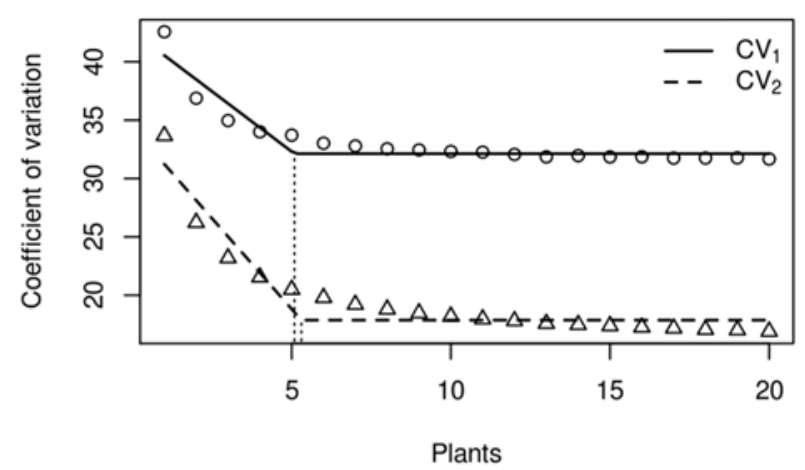

Relative CV model $(q=0.15)$

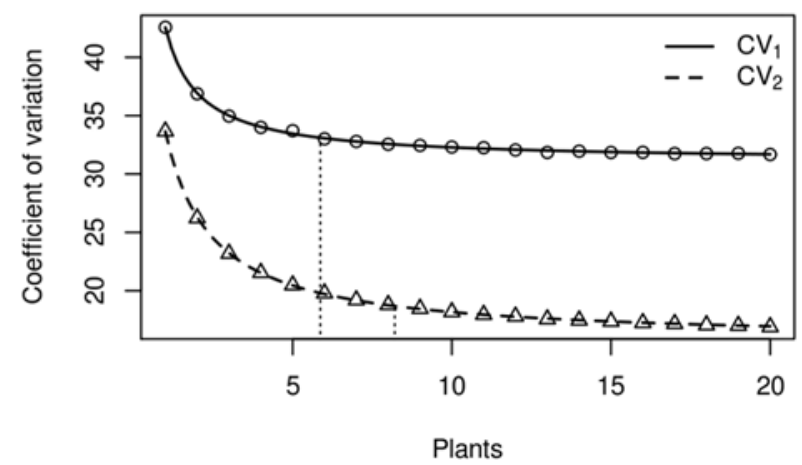

Figure 1. Minimum number of plants per plot according to the following methods: maximum curvature, segmented linear model, quadratic segmented model, and the relative CV model, in the evaluation of common bean resistance to white mold by the straw test.

The CV value decreased with increasing number of plants per plot, and became stable when the plot contained seven plants by the methods of maximum curvature and quadratic segmented model and with five plants by the linear method. By the relative $\mathrm{CV}$ model, the optimal number of plants per plot was eight when $\mathrm{q}=0.15$, that is, $15 \%$ more variation than the minimum CV (Figure 1). The $q$ values $5 \%, 10 \%, 20 \%$ and $25 \%$ require $28,13,6$, and 4 plants per plot, respectively (Table 2).

It was confirmed that a number of 10 bean plants per plot, inoculated with different isolates, was more than enough for an adequate evaluation by the applied methods. It is noteworthy that with eight plants per plot, normality of residuals was obtained by the Shapiro-Wilk test, which is a presumption of analysis of variance that must be satisfied for the validity of the inferences, but is often not met when the response variable corresponds to levels on a diagrammatic scale. Therefore, eight plants per plot seem to be an adequate number to assess the reaction to white mold in common bean, with good experimental accuracy.

In an experiment to evaluate white mold resistance in common bean in a greenhouse, Terán and Singh (2009) used the straw test, with three plants per plot. However, environmental conditions in a greenhouse are more uniform than in the field, so the experimental accuracy can be good even with a smaller number of plants per plot. This was evidenced by Cocco et al. (2009), who noted that the estimated difference between treatment means of strawberry was greater in soil-grown strawberries (20.57\% - $46.11 \%)$ while in hydroponic cultivation the range was smaller $(13.99 \%-31.36 \%)$. These authors estimated that the optimal plot size is 10 for soil-grown and six for plants in hydroponic culture. These results illustrate the greater variability found in soil cultivation which calls for greater differences between treatment means, to be considered statistically different. 
The determination of the minimum number of plants per plot is important not only in terms of costs and labor reduction, but also in the evaluation of segregating population, where the researcher will evaluate either a large number of progenies, resulting from a small number of crosses or evaluate many crosses, each with few descendants. If few individuals allow an adequate evaluation of a certain cross, many crosses can be evaluated simultaneously. A smaller number of plants that adequately represents a progeny, preserving its genetic properties, will allow the simultaneous evaluation of many progenies.

For common bean in Brazil, there are to date no studies on field resistance to white mold using the straw test, or on the minimum number of plants per plot. The results of this study may therefore be useful for future research, with the finding that eight plants per plot are an adequate basis to evaluate the reaction of common bean to white mold.

\section{ACKNOWLEDGEMENTS}

We thank the Brazilian Federal Agency for Support and Evaluation of Graduate Education (CAPES), the National Council for Scientific and Technological Development (CNPq) and Research Foundation of the State of Minas Gerais (FAPEMIG).

\title{
Número mínimo de plantas por parcela para avaliar a resistência em campo do feijoeiro ao mofo branco
}

\begin{abstract}
RESUMO - O presente trabalho teve como objetivo determinar o número mínimo de plantas por plota para avaliar a resistência do feijoeiro ao mofo branco em campo. Treze cultivares foram inoculadas com seis isolados de Sclerotinia sclerotiorum. $O$ delineamento utilizado foi o de blocos casualizados com três repetições, com plota constituída de quinze plantas por metro linear. A inoculação foi realizada utilizando o método do straw test. Oito dias após a inoculação foi realizada a avaliação utilizando uma escala diagramática de 1 (plantas assintomáticas) a 9 (morte da planta). Foram utilizados os métodos: curvatura máxima, modelo segmentado linear, modelo segmentado quadrático e o modelo CV relativo, para determinar o número mínimo de plantas por plota. Houve diferença significativa entre as cultivares, entre os isolados e entre a interação cultivares $x$ isolado. Observou-se que oito plantas por plota é um número adequado para avaliar a reação de feijoeiro ao mofo branco.
\end{abstract}

Palavras-chave: melhoramento genético, Sclerotinia sclerotiorum, delineamento experimental, resistência à fitopatógeno.

\section{REFERENCES}

Barbosa MHP, Peternelli L A and Silveira LCI (2001) Plot size in sugarcane family selection experiments. Crop Breeding and Applied Biotechnology 1: 271-276.

Boland G J and Hall R (1994) Index of plant hosts of Sclerotinia sclerotiorum. Canadian Journal of Plant Pathology 16: 93-108.

Cocco C, Boligon AA, Andriolo JL, Oliveira CS and Lorentz LH (2009) Tamanho e forma de plota em experimentos com morangueiro cultivado em solo ou em hidroponia. Pesquisa Agropecuária Brasileira 44: 681-686.

Eberhart SA (1970) Factors affecting efficiencies of breeding methods. African Soils 15: 669-680.

Ender M and Kelly JD (2005) Identification of QTL associated with white mold resistance in common bean. Crop Science 45: 2482-2489.
Kolkman JM and Kelly JD (2002) Agronomic traits affecting resistance to white mold in common bean. Crop Science 42: 693-699.

Kolkman JM and Kelly JD (2003) QTL conferring resistance and avoidance to white mold in common bean. Crop Science 43: 539-548.

Leite MSO, Peternelli LA and Barbosa MHP (2006) Effects of plot size on the estimation of genetic parameters in sugarcane families. Crop Breeding and Applied Biotechnology 6: 40-46.

Lobo Jr M and Nasser LCB (2007) Mofo branco pode limitar o agronegócio da soja, feijão e girassol em áreas infestadas. Informativo Agromen 4: 6-8.

Miklas PN, Johnson WC, Delorme R, Riley RH and Gepts P (2001) Inheritance and QTL analysis of physiological resistance to white mold in common bean G122. Crop Science 41: 309315 . 
FF Carneiro et al.

Miklas PN (2007) Marker-assisted backcrossing QTL for partial resistance to Sclerotinia white mold in dry bean. Crop Science 47: $935-942$.

Parlevliet JE (1981) Disease resistance in plants and its consequences for plant breeding. In Frey KJ (ed.) Plant breeding II. The Iowa State University Press, Ames, p. 309364 .

Ramalho MAP, Perreira DF and Oliveira AC (2005) Experimentação em genética e melhoramento de plantas. $2^{\text {nd }} E d, U F L A$, Lavras, 326p.

Resende MDV and Duarte JB (2007) Precisão e controle de qualidade em experimentos de avaliação de cultivares. Pesquisa Agropecuária Tropical 37: 182-194.

Resende MDV (2002) Genética biométrica e estatística no melhoramento de plantas perenes. Embrapa Informação Tecnológica, Brasília, 975p.

Robinson RA (1996) Return to resistance - breeding crops to reduce pesticide dependence. AgAccess, Davis, 480p.

SAS Institute (2005) Statistic guide for personal computers. Version 9.1.3., SAS Institute, Cary, 220p.

Silva MGM, Santos JB and Abreu AFB (2006) Seleção de famílias de feijoeiro com resistência a antracnose e mancha angular. Pesquisa Agropecuária Brasileira 41: 1499-1506.
Storck L, Oliveira SJR, Garcia DC and Bisognin DA (2005) Comprimento e largura do tamanho ótimo da plota experimental em batata. Ciência Rural 35: 1043-1048.

Storck L, Bisognin DA and Oliveira SJR (2006) Dimensões dos ensaios e estimativas do tamanho ótimo de plota em batata. Pesquisa Agropecuária Brasileira 41: 903-909.

Terán H and Singh SP (2009) Gamete selection for improving physiological resistance to white mold in common bean. Euphytica 25: 271-280.

Vanderplank JE (1963) Plant disease: epidemics and control. New York, Academic Press, 349p.

Viana AES, Sediyama T, Cecon PR, Lopes SC and Sediyama MAN (2002) Estimativas de tamanho de parcela em experimentos com mandioca. Horticultura Brasileira 20: 58-63.

Zhang R, Warrick AW and Myer DE (1994) Heterogeneity, plot shape effect and optimum plot size. Geoderma 62: 183-197.

Zanon MLB and Storck L (2000) Tamanho ótimo de plotas experimentais para Eucalyptus saligna smith em dois estádios de desenvolvimento. Cerne 6: 104-111. 